\title{
The Islands of Innovation Model: Opportunities and Threats for Effective Implementation of Technological Innovation in the Education System
}

\author{
Orit Avidov-Ungar and Yoram Eshet-Alkakay \\ Dept. of Education and Psychology, Open University, \\ Raanana, Israel
}

oritav@openu.ac.il; yorames@openu.ac.il

\begin{abstract}
In recent years, there have been an increasing number of educational technology-integration projects which employ the Islands of Innovation model. According to this model, technological innovation is implemented in small islands within an organization, in the hope that they will be imitated, permeate the whole organization with their values and lead to overall, comprehensive innovation and to a new organizational culture.

Islands of innovation are created through two main mechanisms: top-down management decisions or bottom-up, spontaneous local initiatives taken by enthusiasts within the organization. Studies on technological innovation implementation in education systems show that for the most part, islands of innovation fail to generate overall, comprehensive innovation. This article uses three prominent organizational theories - Institutional Theory, Loosely Coupled System Theory and Disruptive Technology Theory - to analyze the primary reasons for these failures. It stresses the buffering effect as an isolating mechanism, detaching the islands of innovation from the organization as a whole, and sees it as the main cause of failure in innovation implementation. The article warns against the stagnation that these islands of innovation may cause organization managements, which use them as an excuse to consider themselves innovative, and warns against unsupervised, poorly thought-out use of this model for technological innovation implementation.
\end{abstract}

Keywords: islands of innovation, technological innovation, technology integration, institutional theory, loosely coupled system theory, disruptive technology theory.

\section{Introduction}

Modern digital technologies - particularly multimedia and ICT - are characterized by a transition from systems that are closed, static and monistic to ones that are open, dynamic and pluralistic, ones which enable broad access to information and knowledge and invite social and scholastic

Material published as part of this publication, either on-line or in print, is copyrighted by the Informing Science Institute. Permission to make digital or paper copy of part or all of these works for personal or classroom use is granted without fee provided that the copies are not made or distributed for profit or commercial advantage AND that copies 1) bear this notice in full and 2) give the full citation on the first page. It is permissible to abstract these works so long as credit is given. To copy in all other cases or to republish or to post on a server or to redistribute to lists requires specific permission and payment of a fee. Contact Publisher@InformingScience.org to request redistribution permission. interactions that transcend the constraints of time and place. These technologies offer a new interpretation of concepts such as learning, school, authority and the teacher-student relationship (Alexander, 2006; Anderson, 2004; Venezky \& Davis, 2002). The widespread penetration of these technologies into all levels of education and training in recent years has dictated considerable changes in teaching-learning-training 
processes (Aviram, 2000; Kozma, 2002). This is evident in the formulation of new technologyoriented pedagogical concepts (Koehler \& Mishra, 2009).

During the past decade, we have witnessed extensive implementation of educational technology as an integral part of teaching, learning and training processes (Cunningham, 2009; De Freitas \& Oliver, 2005; Fullan \& Smith, 1999; Halverson \& Smith, 2010; Selwyn, 2010). This involves the development of unique strategies for adapting multimedia and computer technologies to educational needs and projects of innovative technology implementation such as the 'interactive board', the 'computer for every teacher' or the 'computer for every student'.

Analysis of contemporary professional literature reveals that despite the immense inherent potential of educational technologies to enhance and improve teaching, learning and training, educational systems usually resist the organizational and pedagogical changes that result from their implementation (Charter, 2008; Fullan, 2001; Levin \& Fullan, 2008). This resistance presents severe obstacles to the implementation process, which lead to disappointment from the limited impact the technologies have on the school culture (Cuban, 1986), a disappointment that is common to most such endeavors (Fullan \& Smith, 1999; Mioduser, Nachmias, Tubin and Forkosh, 2006). As early as 1987, Papert aptly described the stagnation of the education system and its resistance to technological innovation, when he formulated his implementation paradox, claiming that "the more suited innovative technologies are to the existing system and the fewer changes needed to implement them, the more marginal the impact they will have" (Papert, 1987).

Studies on technological innovation implementation in education systems show that contrary to the recommendations for leading models of innovation implementation (Levin \& Fullan, 2008; Rogers, 1995; Tyack \& Cuban, 1995), the decision about how innovations should be implemented in education systems is usually an imposed top-down policy, that does not involve principals and teachers, and does not take into account the organizational culture, practices, norms and inherent resistance to change (Ogobonna \& Harris, 2003; Vaillant, 2005; Zimmerman, 2006). The research literature also indicates that most projects tend to ignore the need for a change in the organization's culture, norms and basic assumptions (Schein, 1990) as a prerequisite for effective, meaningful implementation of innovation (Fullan, 2006; Hargreaves \& Goodson, 2006; White, 2007).

The search for suitable methods of implementation has led education system leaders over the past decade to examine effective implementation strategies (Sarason, 1995). In contemporary literature we find two main implementation models: Islands of Innovation and Comprehensive Innovation. In the Islands of Innovation model, the innovation encompasses only a small part of the organization and is usually focused on a particular content area or a particular task (Mioduser et al, 2006). This model usually leads to first degree changes which mainly involve changes in the characteristics and behaviors of the organization, without a significant change in the organization's culture, norms and basic assumptions (Argyris \& Schon, 1978; Raz, 2002, 2006). In contrast, in the model of Comprehensive Innovation, the innovation permeates all levels of the organization (Mioduser et al., 2006). It creates a new organizational culture and leads to second degree changes which affect values and basic assumptions in the organization (Argyris \& Schon, 1978; Raz, 2002, 2006). At the highest level, this innovation might even lead to a paradigm shift within the organization (Pelgrum, Brummelhuis, Collis, Plomp, \& Janssen, 1997).

Because of the complexity and high cost of educational technology implementation (Venezky \& Davis, 2002; Fullan, 2001), many organizations choose to employ the Islands of Innovation model (Avidov-Ungar, 2010) for their integration, hoping that these islands will radiate slowly onto their surroundings and lead to comprehensive innovation (Carter, 2008; Day \& Smethem, 2009; Del Val \& Fuentes, 2003). The Islands of Innovation model is attractive for many education systems because it uses up only a small portion of their resources and therefore minimizes the dam- 
age from failure. Because the scope of implementation is limited, the big challenge in a successful implementation of the Islands of Innovation model lies in their successful expansion to the organization as a whole and the creation of a change in its culture, and in particular its values and basic assumptions (Dodgson \& Bessant, 1996; White, 2007).

In this article we compare the two major models of innovative technology implementation (i.e. islands of innovation versus comprehensive innovation), with a special focus on the implications of the Islands of Innovation model for the implementation of innovative technologies in education systems.

\section{Islands of Innovation and Comprehensive Innovation as Models of Educational Technology Implementation}

Recent research findings indicate disappointment from the limited impact of many comprehensive innovative technological reforms in the education system (Fullan, 2001; Venezky \& Davis, 2002). Unclear results emerge from research findings about the effectiveness of the Islands of Innovation model for integrating technological innovation in the education system (AvidovUngar, 2010; Wenglinski, 1998). Many studies reported that not only did the hope that these islands of innovation would expand and become comprehensive innovation prove to be in vain, but also that the islands of innovation themselves were often found to inhibit the wider implementation of technological innovation (Christensen\& Clark, 2003). We will now analyze the two models in an attempt to identify the advantages and disadvantages of each one in terms of effective implementation.

In the Islands of Innovation model, the innovation is implemented only in a small part of the organization and in for a homogeneous group with similar traits. In many cases this is done in the form of a pilot project or a specially-selected group, such as a particular age group, a curricular topic, schools in a certain community, or a particular instruction method. Examples of such pilot projects might be the introduction of laptops into school or examining the effectiveness of learning with video clips in a certain class. In many instances, the choice of the Islands of Innovation model originates from a conservative approach that prefers a gradual introduction of innovation that won't "shake" the organizational culture (Gomez, Sherin, Griesdron \& Finn, 2008; Koehler \& Mishhra, 2009). The assumption common among many proponents of the islands of innovation model is that the success of the islands will serve as a role model, slowly dissipate to the rest of the organization and finally lead to a comprehensive innovation (Kozma, Voogt, Pelgrum, Owston, McGhee, Jones \& Anderson, 2002). On the other hand, in the Comprehensive Innovation model, the implementation of innovative technology is all-encompassing rather than gradual. It consists of heterogeneous groups and involves most of the components of the organization and its members. The comprehensive model derives from the assumption that a successful implementation of innovation requires a radical change in the organization's basic assumptions and the formulation of new organizational paradigms and perspectives (Halverson \& Smith, 2010). Hence, while the Islands of Innovation model is often satisfied with a change within the existing organizational structure, in the comprehensive model the technology is perceived as leading an overall change in the organizational culture (De Freitas \& Oliver, 2005; Fullan, 2006). With respect to a school, this would involve systemic changes, such as in the school structure and the role of the teacher.

Many recent studies suggest the critical importance of matching the implementation model to the organizational culture and stress the impact of that choice on the effectiveness of the implementation (Carter, 2008; De Freitas \& Oliver, 2005;). On the other hand, other studies reveal that in many instances, the choice of implementation model is not made out of a deep analysis of the 
goals and limitations of the implementation or of the organizational culture into which it is to be introduced (Ben Perez, 2009).

Table 1 compares the two models, islands of innovation and comprehensive innovation, using parameters of organizational change (Sarason, 1995).

Table 1: Comparison of the Islands of Innovation and Comprehensive Innovation models, using parameters of organizational change

\begin{tabular}{|c|c|c|}
\hline $\begin{array}{l}\text { parameters of or- } \\
\text { ganizational } \\
\text { change }\end{array}$ & $\begin{array}{c}\text { Islands of Innovation } \\
\text { Model }\end{array}$ & $\begin{array}{c}\text { Comprehensive Innovation } \\
\text { model }\end{array}$ \\
\hline Goal of change & $\begin{array}{l}\text { Improvement of existing structures; } \\
\text { changes in behavior, language and } \\
\text { symbols }\end{array}$ & $\begin{array}{l}\text { Overall change in organizational } \\
\text { culture; a new structure based on } \\
\text { new values and worldview }\end{array}$ \\
\hline Depth of change & $\begin{array}{l}\text { Innovation encompasses only a } \\
\text { small part of the members learning } \\
\text { and teaching in the organization }\end{array}$ & $\begin{array}{l}\text { Innovation encompasses at least } \\
\text { half of the members learning and } \\
\text { teaching in the organization }\end{array}$ \\
\hline Type of change & $\begin{array}{l}\text { A conservative approach; } \\
\text { innovation leading to changes de- } \\
\text { fined as first degree }\end{array}$ & $\begin{array}{l}\text { A systemic approach; innovation } \\
\text { leading to changes defined as sec- } \\
\text { ond degree }\end{array}$ \\
\hline Focus of change & $\begin{array}{l}\text { Innovation is focused on specific } \\
\text { content or a specific task }\end{array}$ & $\begin{array}{l}\text { Innovation involves most compo- } \\
\text { nents of the organization with di- } \\
\text { rect implications for the values and } \\
\text { worldview of the organization }\end{array}$ \\
\hline $\begin{array}{l}\text { Structural fea- } \\
\text { tures }\end{array}$ & $\begin{array}{l}\text { An operational change of a particu- } \\
\text { lar parameter within the organiza- } \\
\text { tional system without changing any } \\
\text { of its definitions; } \\
\text { the innovation has no significant } \\
\text { impact on other levels of the organ- } \\
\text { izational culture. }\end{array}$ & $\begin{array}{l}\text { A change in the features and defi- } \\
\text { nitions of the organization that } \\
\text { becomes of essential value, one } \\
\text { that directly affects role variables } \\
\text { and creates a 'new culture' }\end{array}$ \\
\hline $\begin{array}{l}\text { Principal imple- } \\
\text { menters }\end{array}$ & $\begin{array}{l}\text { A particular, unique, homogenous } \\
\text { 'audience' }\end{array}$ & $\begin{array}{l}\text { An 'audience' with a broad popu- } \\
\text { lation that is varied and heteroge- } \\
\text { neous }\end{array}$ \\
\hline $\begin{array}{l}\text { Organizational } \\
\text { culture compo- } \\
\text { nents }\end{array}$ & $\begin{array}{l}\text { Innovation involves mainly the lev- } \\
\text { el of characteristics and behaviors. }\end{array}$ & $\begin{array}{l}\text { Innovation encompasses all layers } \\
\text { of the organization including val- } \\
\text { ues and basic assumptions }\end{array}$ \\
\hline
\end{tabular}

Both models of implementation have the potential for coping successfully with the complexity and the problems involved in technology-innovation implementation. The success depends to a great extent on a profound understanding of the advantages and disadvantages and the dilemmas each innovation poses (Bransford, Brown, \& Cocking, 1999). Research literature describes seven key dilemmas pertinent to the implementation of innovation in education systems (Ogawa, Crowson, Goldring, 1999). These dilemmas relate to the processes of change that schools undergoe during implementation and to their relation to the schools environment. These dilemmas are presented in Table 2, with reference to the advantages and disadvantages of each implementation 
model to them. The first four dilemmas in the table refer to the relationships between sub-systems within the school and the remaining three refer to the relations between the school and its environment.

Table 2: Comparison of the Islands of Innovation model and the Comprehensive Innovation model in terms of common dilemmas of innovation implementation

(Ogawa, Crowson, \& Goldring, 1999)

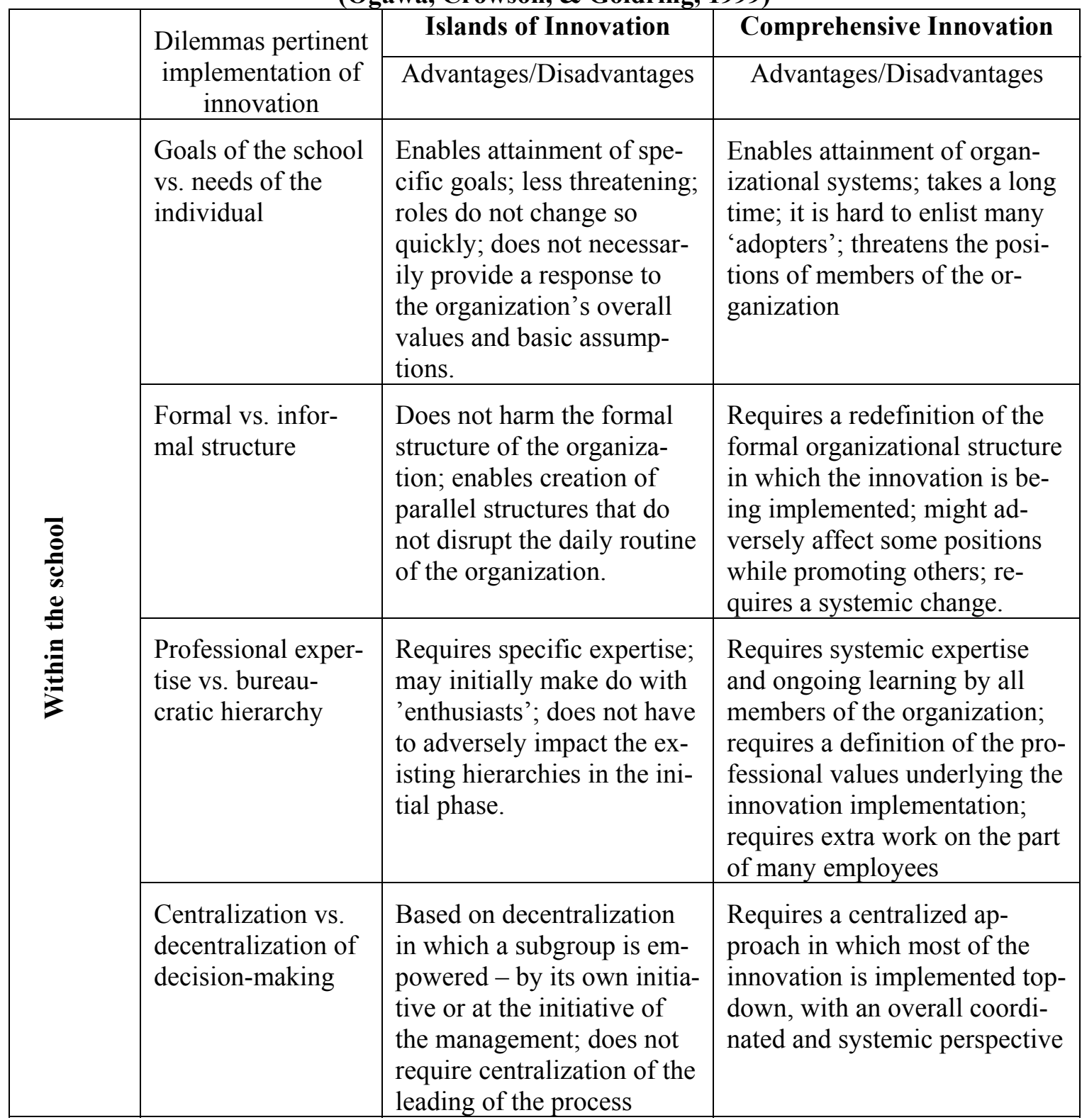




\begin{tabular}{|c|c|c|c|}
\hline \multirow{3}{*}{ 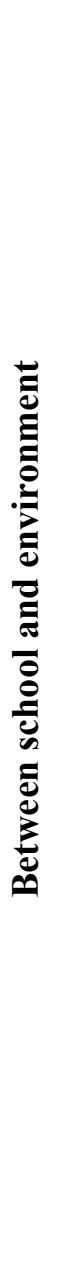 } & $\begin{array}{l}\text { Conservatism vs. } \\
\text { flexibility }\end{array}$ & $\begin{array}{l}\text { Enables organizational } \\
\text { conservatism as the sys- } \\
\text { temic perspective but at the } \\
\text { same time acts flexibly vis- } \\
\text { à-vis the local innovation; } \\
\text { partially caters to the de- } \\
\text { mands of the environment } \\
\text { to be flexible and innova- } \\
\text { tive regarding implement- } \\
\text { ing technologies in the } \\
\text { school }\end{array}$ & $\begin{array}{l}\text { Harder to remain conservative } \\
\text { when implementing an overall } \\
\text { systemic change; mental and } \\
\text { organizational flexibility is } \\
\text { needed to activate the change } \\
\text { properly. }\end{array}$ \\
\hline & $\begin{array}{l}\text { Internal cohesion } \\
\text { vs. openness to the } \\
\text { environment }\end{array}$ & $\begin{array}{l}\text { Does not adversely affect } \\
\text { internal cohesion. Enables } \\
\text { each sub-unit to function } \\
\text { alone according to its rou- } \\
\text { tines; does not require max- } \\
\text { imum openness to the envi- } \\
\text { ronment; the environment } \\
\text { 'penetrates' the organiza- } \\
\text { tion only through the 'is- } \\
\text { lands of innovation' }\end{array}$ & $\begin{array}{l}\text { Often adversely affects inter- } \\
\text { nal cohesion, creating contro- } \\
\text { versy regarding a systemic } \\
\text { implementation that disrupts } \\
\text { daily routine; innovation en- } \\
\text { ables the intake of 'oxygen' } \\
\text { from the environment, usually } \\
\text { in the form of innovation }\end{array}$ \\
\hline & $\begin{array}{l}\text { Obeying technical } \\
\text { expectations of } \\
\text { environment } \\
\text { (achievements) vs. } \\
\text { symbolic expecta- } \\
\text { tions (values) }\end{array}$ & $\begin{array}{l}\text { 'Islands of innovation' } \\
\text { spare the organization from } \\
\text { systemic confrontation of } \\
\text { achievements vs. values } \\
\text { dilemma; enables small- } \\
\text { scale tryout without damag- } \\
\text { ing the organization }\end{array}$ & $\begin{array}{l}\text { 'Comprehensive innovation' } \\
\text { forces the organization to con- } \\
\text { front the dilemma of achieve- } \\
\text { ments vs. values, obligating it } \\
\text { to state what the innovation is } \\
\text { meant to cater to and how. }\end{array}$ \\
\hline
\end{tabular}

Given the rise in the costs and complexity of technological innovation implementation projects, in recent years, the model of Islands of Innovation has become the preferred implementation strategy for decision-makers in the education system and in industrial organizations (Mioduser et al., 2006). Due to their limited successes of these projects, it is important is to understand how islands of innovation are form and what factors encourage or hinder their implementation.

\section{The Formation of Islands of Innovation}

Contemporary literature reports on the formation of islands of innovation in the education system through two main channels: (a) formation through an organized top-down process of carrying out a policy guided by the system's decision-makers (Morgan, 1992) and (b) formation through spontaneous bottom-up processes, led by highly motivated teachers and other enthusiasts members in the organization, who lead innovative initiatives (Mioduser, Nachmias, Tubin, \& Forkosh, 2003). Table 3 compares these two patterns of formation as a basis for a further discussion of the diffusion of technological innovations in organizations. 
Table 3: Two patterns of formations of Islands of Innovation

\begin{tabular}{|c|c|c|}
\hline & Top-down Islands of Innovation & Bottom-up Islands of Innovation \\
\hline \multirow[t]{5}{*}{ Policy-making } & Outcome of overall systemic policy & Outcome of local school initiative \\
\hline & Predefined outcome & $\begin{array}{l}\text { Outcome develops during a localized } \\
\text { implementation approach }\end{array}$ \\
\hline & $\begin{array}{l}\text { Overall centralized approach to the } \\
\text { implementation process }\end{array}$ & Process dependent on the school \\
\hline & $\begin{array}{l}\text { School is obligated by policy- } \\
\text { makers to be part of the process }\end{array}$ & $\begin{array}{l}\text { There is choice within the school re- } \\
\text { garding the depth of involvement in the } \\
\text { process }\end{array}$ \\
\hline & $\begin{array}{l}\text { Expertise from above - from policy- } \\
\text { makers to the school }\end{array}$ & $\begin{array}{l}\text { Springs from below - a local, school- } \\
\text { based initiative }\end{array}$ \\
\hline \multirow[t]{4}{*}{ School } & $\begin{array}{l}\text { Source of knowledge is external to } \\
\text { the school, lying with the policy- } \\
\text { makers in charge of the change }\end{array}$ & $\begin{array}{l}\text { Source of knowledge is within the } \\
\text { school, lying with those who instigated } \\
\text { the change }\end{array}$ \\
\hline & $\begin{array}{l}\text { Minimal partnership of the school in } \\
\text { the planning and initial dissemina- } \\
\text { tion }\end{array}$ & $\begin{array}{l}\text { Maximal partnership between school } \\
\text { stakeholders who are partners to the } \\
\text { innovative change }\end{array}$ \\
\hline & $\begin{array}{l}\text { Derives from system's needs at the } \\
\text { national/local authority level and } \\
\text { from policy }\end{array}$ & Derives from local school needs \\
\hline & $\begin{array}{l}\text { Run by elements external to the } \\
\text { school at the "head office" level }\end{array}$ & $\begin{array}{l}\text { Run by elements within the school, } \\
\text { position holders and teachers who are } \\
\text { particular enthusiasts }\end{array}$ \\
\hline \multirow[t]{3}{*}{ Teachers } & $\begin{array}{l}\text { Teacher are rarely involved in the } \\
\text { decision-making }\end{array}$ & $\begin{array}{l}\text { Only the implementers are involved in } \\
\text { the decision-makers, not the other } \\
\text { teachers }\end{array}$ \\
\hline & $\begin{array}{l}\text { Teachers implement according to } \\
\text { guidelines given "from above" }\end{array}$ & $\begin{array}{l}\text { Implementation is the outcome of the } \\
\text { school initiative }\end{array}$ \\
\hline & $\begin{array}{l}\text { Based mainly on models built out- } \\
\text { side the school }\end{array}$ & $\begin{array}{l}\text { Based on a local model constructed as } \\
\text { part of the innovation }\end{array}$ \\
\hline \multirow[t]{3}{*}{$\begin{array}{l}\text { Implications of } \\
\text { for school-wide } \\
\text { implementation }\end{array}$} & $\begin{array}{l}\text { An element in the framework of the } \\
\text { learning (a course, a website, an } \\
\text { online project, a virtual space) that } \\
\text { expands the students' learning envi- } \\
\text { ronment }\end{array}$ & $\begin{array}{l}\text { For a relatively small number of stu- } \\
\text { dents acting within a very clear frame- } \\
\text { work }\end{array}$ \\
\hline & $\begin{array}{l}\text { Integrates into the timetable and } \\
\text { agenda and contributes to the ad- } \\
\text { vancement of the curriculum }\end{array}$ & $\begin{array}{l}\text { The implementation framework is fo- } \\
\text { cused on one defined content area or } \\
\text { task }\end{array}$ \\
\hline & $\begin{array}{l}\text { Orientation is the outcome of an } \\
\text { overall policy }\end{array}$ & $\begin{array}{l}\text { Orientation is towards the world out- } \\
\text { side the school i.e. image, research, hi- } \\
\text { tech, media, other cultures and the } \\
\text { community }\end{array}$ \\
\hline
\end{tabular}


Contemporary research studies examining the implementation mechanisms for technological innovation in education systems indicate that in general, islands of innovation do not manage to break through their natural boundaries to become comprehensive innovation within the organization (Christensen \& Clark, 2003; Christensen, Baumann, Ruggles \& Sadtler, 2006). AvidovUngar (2010) examined one such implementation process in islands of innovation which were created in a top-down mechanism, as part of a management-dictated policy. She found that the failure of the islands of innovation to transfer the innovation to the entire organization and become comprehensive innovation has two main causes: (a) the size of the gap between the overt level (characteristics) and the covert level (values and basic assumptions) of the organizational culture, and (b) the size of the gap between the management's view of the innovation implementation and that of the teachers. In another study, which examined islands of innovation created through the bottom-up approach, initiated by teachers and other enthusiasts in the organization (Darling Hammond, 2000), it was found that spontaneous islands of innovation which originated by local initiatives tended to have a short lifespan. She claimed that the failure of spontaneous islands of innovation indicates a need for systemic support, particularly from the relevant decision makers and managers.

In research studies of islands of innovation, and particularly of experimental pilots for selected groups within an organization, the buffering effect is described as the main impediment to the spread of the innovation beyond its original boundaries (Avidov-Ungar, 2010; Cook, Holly, \& Andrew, 2007). According to these studies, the islands of innovation are perceived by the rest of the organization as a kind of 'elite unit' that cannot be imitated on the one hand, and on the other, management sees it as proof that the organization is being innovative and reformative, and thus it stops looking to generate further innovation. In this way, the islands of innovation create a buffering process that is harms the transfer of innovation from the islands to the rest of the organization: between the islands and the staff and between the management and the environment in which it functions. Examining the buffering effect in technological innovation implementation in schools, Mioduser et al. (2003) describe how the isolating of the islands of innovation from other activities in the organization rendered these special projects marginal and lacking in influence, even though the initiative for the innovation came from a group of highly motivated teachers and was supported by the management. Support for this observation can also be found in J. Meyer \& Scott (1983), who studied the development of spontaneous islands of innovation. They claimed that because of the buffering effect and because of the lack of awareness on the part of the management regarding the stagnation that these spontaneous islands might create, in many cases the islands actually become the main force impeding expansion of the change to the rest of the organization. A similar phenomenon of "innovation without change" attributed to islands of innovation is reported on in various studies as one of the most prominent features in organizational change and technological innovation in education systems (Avidov-Ungar, 2010; Mioduser et al., 2006; Sarason, 1995; Tyack \& Cuban, 1995). It was found that in general, islands of innovation, particularly the spontaneous ones, that do not constitute part of the management's long-range vision and which do not receive support, do not manage to expand, or radiate to the rest of the organization to become comprehensive innovation (Hanson, 2001). On the other hand, the literature testifies to the tremendous vitality of the spontaneous, bottom-up islands of innovation when they do enjoy management support (Kozma, 2000).

\section{Discussion}

The phenomenon of technological innovation implementation through islands of innovation has expanded in recent years, either through the spontaneous bottom-up approach or through topdown systemic processes motivated by decision-makers who hope that these islands will be the epicenter from which the innovation will spread throughout the organization to become comprehensive. An analysis of the cases and mechanisms discussed in this article reveals that the condi- 
tions under which the islands of innovation are created will greatly impact their chances of radiating out to the rest of the organization. It was found that bottom-up processes often widen existing gaps between an organization's overt characteristics and its covert values and basic assumptions (Avidov-Ungar, 2010). This may be expressed, for example, in the gaps in expectations, worldview and values between the school management and the teachers, or between educational policymakers (Tyack \& Cuban, 1995; Sizer, 1993). There are also significant gaps among the partners to top-down implementation. In many cases, technology innovation implemented in this manner is perceived by the management as a tool and not as a value, and so the motivation for implementation comes from external pressures exerted on the system by policy makers or by the need to resemble competing organizations (Carter, 2008; Cunningham, 2009), without a clear definition of the need that the new technology is supposed to cater to (Cook, Holley, \& Andrew, 2007; Darling Hammond, 2000). Such processes are typical of many of the decisions to implement technological innovation in education systems and in other organizations that are centralist by nature (Koberg, Detienne, \& Heppard, 2003), and they cause widening the gaps between the levels of the organization that are not part of the decision-making process and damage the quality of the implementation (Luo, Hitly, Worlet, \& Yager, 2006). The most common finding regarding these gaps underlines the fact that islands of innovation created during the implementation are perceived by the environment as inaccessible and they become isolated, which, to a great extent, limits the degree to which they can spread to the rest of the organization (Zhang, 2010).

From the findings of the abovementioned studies examining the processes of technology implementation through islands of innovation, it emerges that the assumption that their success will automatically permeate the rest of the organization is erroneous (McDermott \& O'Connor, 2002; White, 2007) and that the buffering effect would seem to be the main impediment to this permeation, both because of the isolation from the rest of the organization and because they create among decision makers an excuse to consider their organization innovative, contrary to reality (Kozma, 2000).

The buffering effect and the difficulties in the transition from islands of innovation to comprehensive innovation can be explained by three prominent organizational theories: the Institutional Theory, the Loosely Coupled System and the Disruptive Technology theory.

According to Institutional Theory, (DiMaggio \& Powell, 1983; Powell \& DiMaggio, 1991; Scott, 2001), organizations aspire to increase their survivability and earn legitimacy by resembling their environment and meeting the challenges it presents (Avgerou, 2000). This theory describes how change is perceived by the organization as a purposeless ritual conducted mainly in order to keep it in tune with external fashions of management and thereby earn social legitimacy. The implementation of technological innovation as part of a policy imposed from above is often seen by the organization as something that disrupts its ongoing, routine activity (Butler, 2003). This theory also suggests that the organization handles this situation by creating islands of innovation which seemingly show it to be meeting the challenge posed by the system, but because these islands are created in order to satisfy the system, they actually block the creation of the desired systemic change (Bada, Anieboran, \& Owei, 2004).

The difficulty of turning islands of innovation into comprehensive innovation and the fact that these islands actually hinder the implementation of spread of innovation throughout the organization may also be explained by the Loosely Coupled System theory (Orton \& Weick, 1990; Weick, 1976, 1982). This theory claims that well-compartmentalized and hierarchical organizations, such as schools, keep loose ties and limited interaction between their different units in order to preserve their identity and independence and to "protect" themselves from changes imposed from above (H. D. Meyer, 2002). According to this theory, the loose ties between the units impede any steady flow of knowledge within the organization and impede the dissemination of innovation (Lance, 2002). As a result, buffers are created within the organization between the islands of in- 
novation and the other units and so the desired expansion of innovation proves impossible (. For example, in a study on introducing a management system in school, it was found that each unit retained its identity and independence and continued to function with very weak connections to the other units (Telem \& Avidov, 1996). It is important to note that the problematic aspect of disseminating innovation within organizations with loosely coupled system units is not unique to schools but can also be found in other organizations such as the military or the government (Lance, 2002; H. D. Meyer, 2002; Weick, 1976, 1982).

The Disruptive Technology theory (Christensen \& Clark, 2003; Christensen, et al.2006) suggests that the implementation of technological innovation might disrupt the activities and performance of the organization if implemented before they have been optimally developed or when the organization itself is not ripe for such implementation (Christensen \& Clark, 2003). In terms of this theory, we can say that in many cases, the difficulty in adopting the model of islands of innovation and having them turn into comprehensive innovation lies in the organization's lack of readiness to absorb the technology and in the reluctance of the decision-makers to adopt a comprehensive implementation approach (Christensen et al., 2006), which will eventually lead to a disruption in the innovation dissemination process.

In conclusion, although this article concentrated on islands of innovation in the context of schools, the analysis of the research findings it presents shows that many of the conclusions regarding the implementation mechanism of islands of innovation are also valid for other organizations, particularly ones that are hierarchical and compartmentalized, such as the military and the government, and which confront similar challenges in implementing technological innovation where the islands of innovation might also impede effective dissemination of the innovation (; Lance, 2002; H. D. Meyer, 2002).

\section{Conclusions}

Today, islands of innovation constitute a common model for leading and implementing organizational and technological changes in education systems (Carter, 2008; Day \& Smethem, 2009; Del Val \& Fuentes, 2003; Mioduser et al., 2006). This article analyzes the main factors involved in the processes of disseminating technological innovation by way of the islands of innovation model. The article presents reservations regarding this model and offers explanations for the difficulties education systems encounter in turning islands of innovation into comprehensive innovation.

The main conclusions that can be drawn from this analysis are:

- Despite the hope that they will provide leverage for systemic change, islands of innovation might actually hinder the dissemination of the innovation, particularly in organizations characterized by loose internal ties and where there are large gaps in expectations and interests between the partners to the innovation implementation.

- Before the innovation is launched, the organization must clearly define the nature of the change it is meant to cater to, whether it will be local or systemic to the organization's culture.

- When deciding on the preferred model of implementation, it is important to examine its suitability to the culture of the organization in which it is to be implemented.

- In order to weaken the buffering effect and improve the potential for the spread of innovation throughout the organization, the islands of innovation must conduct an ongoing dialogue with their environment - both within the organization and outside it. 


\section{References}

Alexander, B. (2006). Web 2.0: a new wave of innovation for teaching and learning? EDUCAUSE Review, $41(2), 32-44$.

Anderson, T. (2004). Towards a theory of online learning. In T. Anderson \& F. Elloumi (Eds.), Theory and practice of online learning (pp. 8-22). Athabasca University: Canada.

Argyris, C., \& Schon, D. A. (1978). Organizational learning: A theory of action perspective. Reading, Mass: Addison Wesley.

Avgerou, C. (2000). IT and organizational change: An institutionalist perspective. Information Technology \& People, 13(4), 234.

Avidov-Ungar, O. (2010). "Islands of innovation" or "comprehensive innovation." Assimilating educational technology in teaching, learning, and management: A case study of school networks in Israel. Interdisciplinary Journal of E-Learning and Learning Objects (IJELLO), 6, 259-280. Retrieved from http://www.ijello.org/Volume6/IJELLOv6p259-280Avidov704.pdf

Aviram, A., (2000). ICT and education: From computers in the classroom to mindful radical adaptation by education systems to the emerging cyber culture. Journal of Educational Change, 1(4), 331-352.

Bada, A. O., Aniebonam, M. C., \& Owei, V. (2004). Institutional pressures as sources of improvisations: A case study from a developing country context. Journal of Global Information Technology Management, 7(3), 27.

Ben-Peretz, M. (2009). Policy making in education: A holistic approach in response to global changes. Rowman \& Littlefield Education.

Bransford, J., Brown, A., \& Cocking, R. (1999). How people learn: Brain, mind, experience, and school. Washington, DC: National Academic Press.

Butler, T. (2003). An institutional perspective on developing and implementing intranet- and internet-based information systems. Information Systems Journal, 13(3), 209-231.

Carter, E. (2008). Successful change requires more than change management. The Journal for Quality \& Participation, 31(1), 20-23.

Christensen, M., Aaron, S., \& Clark, W. (2003). Disruption in education. Education Review, 38(1), 44.

Christensen, M., Baumann, H., Ruggles, R., \& Sadtler, T. M. (2006). Disruptive innovation for social change. Harvard Business Review, 84(12), 94.

Cook, J., Holley, D., \& Andrew, D. (2007). A stakeholder approach to implementing e-learning in a university. British Journal of Educational Technology, 38(5), 784-794.

Cuban, L. (1986). Teachers and machines: The classroom of technology since 1920. New York: Teachers College Press.

Cuban, L., Kirkpatrick, H., \& Peck, C. (2001). High access and low use of technology in high school classrooms: Explaining an apparent paradox. American Educational Research Journal, 38(4), 813-834.

Cunningham, C. A. (2009). Transforming schooling through technology: Twenty-first-century approaches to participatory learning. Education and Culture, 25(2), 46-61

Darling-Hammond, L. (2000). Policy and change: Getting beyond bureaucracy. In A. Hargreaves, A. Liberman, M. Fullen, \& D. Hopkins (Eds.), International handbook of educational change (pp. 642-667). Kluwer Academic Publishers.

Day, C., \& Smethem, L. (2009).The effects of reform: Have teachers really lost their sense of professionalism? Journal of Educational Change, 10(2-3), 141-157.

De Freitas, S., \& Oliver, M. (2005). Does e-learning policy drive change in higher education? A case study relating models of organizational change to e-leaning implementation. Journal of Higher Education Policy and Management, 27(1), 81-95. 
Del Val, M. P., \& Fuentes, C. M. (2003). Resistance to change: A literature review and empirical study. Management Decision, 41(12), 148-155.

DiMaggio, P. J., \& Powell, W. W. (1983). The iron cage revisited: Institutional isomorphism and collective rationality in organizational fields. American Sociological Review, 48(2), 147-160.

Dodgson, M., \& Bessant, J. (1996). Effective innovation policy: A new approach. London: International Thompson Business Press.

Fullan, M. (2001). The new meaning of educational change (3rd ed.). New-York: Teachers College, Columbia University.

Fullan, M. (2006). The future of educational change: System thinkers in action. Journal of Educational Change, 7(3), 113-122.

Fullan, M., \& Smith, G. (1999). Technology and the problem of change. Available at: http://www.michaelfullan.ca/Articles_98-99/12_99.pdf

Gomez, L. M., Sherin, M. G., Griesdorn, J., \& Finn, L. (2008). Creating social relationships: The role of technology in pre-service teacher preparation. Journal of Teacher Education, 59(2), 117.

Halverson, R., \& Smith, A. (2010). How new technologies have (and have not) changed teaching and learning in school. Journal of Computing in Teacher Education, 26(2).

Hanson, M. (2001). Institutional theory and educational change. Educational Administration Quarterly, $37(5), 637-661$.

Hargreaves, A., \& Goodson, I. (2006). Educational change over time? The sustainability and nonsustainability of three decades of secondary school change and continuity. Educational Administration Quarterly, 42(1), 3-41.

Koberg, C. S., Detienne, D. R., \& Heppard, K. A. (2003). An empirical test of environmental, organizational, and process factors affecting incremental and radical innovation. The Journal of High Technology Management Research, 14(1), 21-45.

Koehler, M. J., \& Mishra, P. (2009). What is technological pedagogical content knowledge? Contemporary issues in Technology and Teacher Education, 9(1), 60-70.

Kozma, R. (2000). Qualitative studies of innovative pedagogical practices using technology. SITES M2 design document, IEA.

Kozma, R., Voogt, J., Pelgrum, W., Owston, R., McGhee, R., Jones, R., \& Anderson, R. (2002). Technology, innovation, and educational change: A global perspective - A report of the second information technology in education study: Module 2, A Project of the IEA. URL: http://sitesm2.org/SITES Research Projects/SITESM2/final report/index.html

Lance, D. F. (2002). Tightly coupled policy in loosely coupled systems: Institutional capacity and organizational change. Journal of Educational Administration, 40(6), 561-575.

Levin, B., \& Fullan, M. (2008). Learning about system renewal. Educational Management Administration \& Leadership, 36(2), 289-303.

Luo, J. S., Hitly, D. M., Worlet, L. L., \& Yager, J. (2006). Considerations in change management related to technology. Academic Psychiatry, 30(6), 465-469.

McDermott, C. M., \& O'Connor, G. C. (2002). Managing radical innovation: An overview of emergent strategy issues. Journal of Product Innovation Management, 19(6), 424-438.

Meyer, H. D. (2002). From "loose coupling" to "tight management"? Making sense of the changing landscape in management and organization theory. Journal of Educational Administration, 40(6), 515 520 .

Meyer, J., \& Scott, W. R. (Eds). (1983). Organizational environments: Rationality and ritual. Beverly Hills: Sage. 
Mioduser, D., Nachmias, R., Forkosh, A., \&Tubin, D. (2003). Educational innovation in online schools in Israel [research report]. Tel Aviv University. (In Hebrew).

Mioduser, D., Nachmias, R., Tubin, D., \& Forkosh, A. (2006). Pedagogical innovation involving information technologies and communications. The Center for Science and Technology Education, School of Education, Tel Aviv University. Ramot, Tel Aviv University. (In Hebrew).

Morgan, R. M. (1992). Educational reform: Top-down or bottom-up? Educational Technology, 32(11) 4751.

Ogawa, R., Crowson, R., \& Goldring, E. (1999). Enduring dilemmas of school organization. In J. Murphy $\&$ K. Seashore Louis (Eds.), Handbook of research on educational administration $\left(2^{\text {nd }} \mathrm{ed}\right.$.) (pp. 277295). San Francisco: Jossey- Bass.

Ogobonna, E., \& Harris, L. C. (2003). Innovation, organizational structure and performance. Journal of Organizational Change Management, 16(5), 512-533.

Orton, J. D., \& Weick, K. E. (1990). Loosely coupled systems: A reconceptualization. Academy of Management Review, 15(2), 203-223.

Papert, S. (1987). Technological thinking versus computer criticism. Educational Researcher, 16(1), 22-30.

Pelgrum, W., Brummelhuis, A., Collis, B., Plomp, Tj., \& Janssen, I. (1997). Technology assessment of multimedia systems for pre-primary and primary schools. European Parliament, Scientific and Technological Options Assessment Panel, Luxembourg.

Powell, W. W., \& Dimaggio, P. J. (1991). The new institutionalism in organizational analysis. Chicago: University of Chicago Press.

Raz, A. (2002). Emotions at work: Normative control, culture and organizations in Japan and America. Harvard University Press (Asia Center).

Raz. A. (2006). Managerial culture, workplace culture and situated curricula in organizational learning. Organization Studies, 27(2), 165-182.

Rogers, E. M. (1995). Diffusion of Innovations (4th ed.). New York: The Free Press.

Sarason, S. B. (1995). The school culture and processes of change. In S. B. Sarason, School change - The development of a point of view (Ch.6, pp.65-84). New York and London: Teacher College, Columbia University.

Schein, E. (1990). Organizational culture. American Psychologist, February, 109-119.

Scott, W. R. (2001). Institutions and organizations. Thousand Oaks, CA: Sage

Selwyn, N. (2010). Looking beyond learning: Notes towards the critical study of educational technology. Journal of Computer Assisted Learning, 26(1), 65-73.

Sizer, T. R. (1993). Horace's school: Redesigning the American high school. Boston: Houghton-Mifflin.

Telem, M., \& Avidov, O. (1996). The effect of school management information systems on the nature of a loosely coupled high school instruction, administration subsystem: A preliminary study. The Journal of Research on Technology in Education, 28(2) 258-270.

Tyack, D., \& Cuban, L. (1995). Tinkering toward utopia. Cambridge: Harvard University Press.

Vaillant, D. (2005). Educational reform and the role of teachers. Prelac Journal, 1, 38-51.

Venezky, R. L., \& Davis, C. (2002). Que Vademus? The transformation of schooling in a networked world. Research report: OECD/CERI, Version 8c, March, 2002.

Weick, K. (1976). Educational organization as loosely coupled systems. Administrative Science Quarterly, 21, 1-19.

Weick, K. (1982). Administering education in loosely coupled schools. Phi Beta Kappan, 63(10), 673-676. 
Wenglinsky, H. (1998). Does it compute? The relationship between educational technology and student achievement in mathematics. Princeton, NJ: Educational Testing Service. From: ftp://ftp.ets.org/pub/res/technolog.pdf.

White, S. (2007). Critical success factors for e-learning and institutional change - Some organizational perspectives on campus-wide e-leaning. British Journal of Educational Technology, 38(5), 840-850.

Zhang, J. (2010). Technology-supported learning innovation in cultural contexts. Educational Technology Research and Development, 58(2), 229-243.

Zimmerman, J. (2006). Why some teachers resist change and what principals can do about it. NASSP Bulletin, 90(3), 238-249.

\section{Biographies}

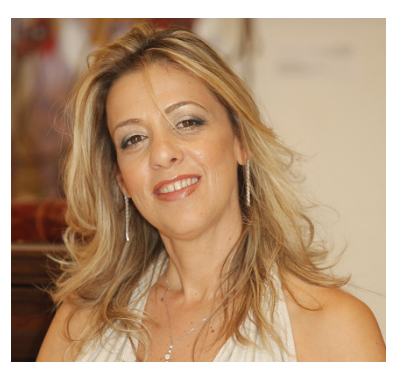

Dr. Orit Avidov-Ungar is a member of the faculty of the Open University in Israel and a senior lecturer at the School of Education Systems Management at Achva College. She heads the specialization in professional development at the School of Professional Development at the Mofet Institute and is the academic advisor to the Ministry of Education management in the implementation of innovative technology systems and the professional development of teachers.

Her areas of expertise are education administration, changes in education systems, and professional development of teachers. Her research studies deal with the implementation of innovative technologies in education systems, the empowerment and professional development of teachers, and leading organizational change in education systems.

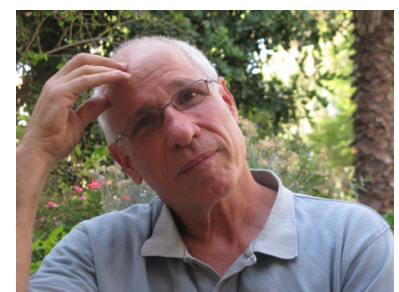

Yoram Eshet is a Full Professor at the Open University of Israel, Department of Education \& psychology. He is the Coordinator of the M.A. program in educational technology and wrote several M.A.-level textbooks on technology \& learning and on design-principles of computer-based learning. He is the Founder and Head of the Research Center for Innovation in Learning Technologies.

Yoram has a diverse academic and professional background: He holds a B.A in Archeology, M.Sc. in Geology and PhD in Earth \& Environmental Sciences. For a decade, he was the Head of the Instructional Design Program in the Tel Hai Academic College and a senior researcher in the Geological Survey of Israel.

Yoram has more than 15 years experience in the educational technology industry - developing technology-based instructional solutions for educational systems in Israel and the USA. In this capacity, he was involved in the design of hundreds of simulations, microworlds, data-bases, tutorials and large-scale curriculum integration projects.

His major research and publications focus mainly on cognitive aspects of working with digital technologies, technology integration in educational systems, digital games and design principles of computer-based learning environments. In geology, his research focuses on chronostratigraphy, mass-extinctions and pleoenvironmental interpretations.

Yoram serves on the editorial board of various international journals, and on the program committees of international conferences.

For a full CV, see: http://www.openu.ac.i1/Personal_sites/yoram-eshet.html 